\title{
PRODUCTIVE AND REPRODUCTIVE PERFORMANCE OF FRIESIAN CATTLE UNDER ASSIUT ENVIRONMENTAL CONDITIONS
}

\author{
HASSAN, A.H ${ }^{1}$; M. ABD-ALLAH ${ }^{2}$; A.I. ZANOUNY ${ }^{1}$ and A.A. AYAD ${ }^{2}$ \\ ${ }^{1}$ Animal Production Department, Faculty of Agriculture, Minia University, Minia, Egypt. \\ ${ }^{2}$ Animal Production Department, Faculty of Agriculture, Al-Azhar University, Assiut, Egypt.
}

Received: 4 September 2018; Accepted: 28 October 2018

\begin{abstract}
Environmental factors such as animal origin, parity, year of calving and season of calving affect productivity. This work focused on the study of the effect of these factors on milk yield and reproductive traits of Friesian cows raised under Upper Egypt conditions. Data used in this investigation were collected from 1975 lactation records of pure Friesian cows raised at the station of Abnoub Alhamam belonging to the project livestock development in Assiut Governorate. The records represented 49 sires and 427 dams during the period from 1987 to 2004. Least squire means and standard errors for the studied traits were estimated using SAS 9.13. The General Linear Model (GLM) was utilized for variance analyses of milk yield and reproductive traits. Duncan's multiple range test (DMRT) was used for multiple comparisons of each trait. Animal origin constituted a significant source of variation in lactation milk yield and 305-days milk yield, while did not have any significant effect on lactation length and dry period. Season of calving had no significant effect on lactation milk yield while it has significant effect on the 305-day milk yield, lactation length and dry period. Parity effect was found to be significant on lactation milk yield, 305-day milk yield and length of lactation period, while it does not have a significant effect on the dry period. Year of calving showed significant effects on lactation milk yield, 305- day milk yield, lactation length and dry period. For reproductive traits animal origin has not had any significant effect on the lactation milk yield. Animal origin had significant effect $(\mathrm{P}<0.01)$ on calving interval and the age at first calving. Season of calving had significant effect $(\mathrm{P}<0.01)$ on days open, calving interval and age at first calving $(\mathrm{P}<0.05)$. All reproductive traits under study were significantly affected by year of calving. The results indicated that Friesian cows born and raised in Egypt were better in some reproductive traits, while imported cows tended to have more total milk yield.
\end{abstract}

Key words: Friesian cows, environmental factors, milk traits, reproductive traits.

\section{INTRODUCTION}

The population of cows in Egypt is continuously increasing and is estimated to be about 5.02 million heads. They produce about 3.21 million metric tons of milk and about 0.32 million metric tons of meat, representing about $53.88 \%$ of the total milk production and $46.69 \%$ of the total meat production, respectively (FAO, 2010). Friesians are examples of a dual purpose breed, they are known as the world's highest-production dairy animals, a fast growing, beefy animal, well suited to continental beef market. The success of selection for milk production has contributed to the domination of the Friesian breed around the world. In Egypt, dairy industry represents $35 \%$ of the total animal production sector. Friesian cattle were introduced to

Corresponding author: M. ABD-ALLAH

E-mail address: mohtaram_a_m_e@yahoo.com

Present address: Animal Production Department, Faculty of Agriculture, Al-Azhar University, Assiut, Egypt.
Egypt to improve the productivity of local cows by crossing and grading, Friesian cows spread in Egypt and became famous and desirable among breeders. During the last two decades, considerable emphasis had been placed upon the importance of Friesian cattle in Egypt for milk production, accordingly the number of large Friesian herds had increased either in the governmental or commercial farms through importation from Europe and USA (Shalaby et al., 2001). The yields of farm animals are the result of the combined effects of genotype and environmental conditions. In order to increase the yield level, it is necessary to optimize the environmental conditions and to improve the genetic structure of the animals (M'hamdi et al., 2012).

In order to enhance productivity of a dairy animal, it is necessary to develop an understanding of the factors affecting its milk production. Environmental factors can be classified as factors with measurable effects (age, year, season, milking frequency, etc.) and factors with immeasurable effects (infectious diseases, parasitic infestations, etc.) (M'hamdi et al., 
2012). Several investigators have screened some of the genetic and non-genetic aspects of productive and reproductive potentialities of that breed under the Egyptian conditions (Shitta et al., 2002; El-Arian et al., 2003; Nadia Fahim, 2004; Sadek et al, 2014 and Salem et al., 2006). The aim of this study is to investigate some environmental factors and their effect on milk production and some reproductive traits of imported and locally born Friesian cows in Egypt.

\section{MATERIALS AND METHODS}

Data used in this investigation were collected from 1975 lactation records of pure Friesian cows raised at the station of Abnoub Alhamam $20 \mathrm{~km}$ north east of Assiut City, Egypt. The herd belong to the livestock development project in Assiut Governorate. Records were collected from 427 cows and 49 sires covering the period from 1987 to 2004 . The nucleus of this herd was imported to Egypt from Netherlands as pregnant heifers in 1984. Data were collected from the records of the imported cows and the locally born cows as well. Lactation without breeding dates and those of aborted cows or those affected by mastitis or other udder disorders were considered as abnormal lactation and their records were excluded from the original data before the statistical analysis. Also, records of sold cows were excluded from the data. Data were organized such that record contained cow number, birth data (day, month, year), season of birth, dam number, sire number, date of calving (day, month, year), season of calving, age at calving in months, parity, lactaition milk yield $(\mathrm{kg}), 305$-day milk yield $(\mathrm{kg})$, length of lactation period (days), length of dry period (days), length of days open (days) and length of calving interval (days). All cows were naturally mated, heifers were mated when they reached body weight of about $300-350 \mathrm{~kg}$. Animals were checked for heat twice daily at morning and evening using a teaser bull. They were mated about 45-60 days after parturition. Pregnancy was routinely diagnosed by rectal palpation after two months from service.

\section{Management, Housing and Nutrition}

Animals were kept loose in under semi open paddock (The height of the side walls is 1.5 meters, the roof is covered with asbestos with the provision of 2.5 meters per animal) in groups of 35-40 throughout the day and night all year round, except during milking and some other specific purposes like treatment, breeding etc., when the animals are required to be tied. All cows were fed concentrate feed mixture, corn silage and rice straw all year round. Egyptian clover (Trifolium Alexandrinum) was provided during winter (December to May), while hay or maize were offered during summer season (June to November) concentrate were offered twice daily before milking according to cows body weight and its milk production. The feed requirements were calculated according to NRC (1975). Cows producing more than $10 \mathrm{~kg}$ a day and those in the last two months of pregnancy were supplemented with extra concentrate rations according to their weight and pregnancy status. Fresh clean water and minerals mixture were fully available. All cows were machine-milked twice a day, at 7 a.m and 4. p.m. milk yield was individually recorded once a week to the nearest kilogram. All cows were observed at puberty for signs of heat every day, and when attainment $60 \%$ of the mature body weight (about $300 \mathrm{~kg}$ ) was mated with superior bulls (Random mating within the herd without genetic improvement on the herd). Prepartum pregnant heifers were supplied with good food, minerals and vitamins, vaccinate against FMD, hemorrhagic septicemia and other diseases, Deworming for external and internal parasites and it was isolated from the herd at the onset of parturition signs. Cows were dried off about two months before expected time of the next calving. If before that time cows did not go dry they were dried gradually by milking them once a day for some time milking, then after once every two days until complete drying. Disposal of cows from the farm of the study if any was done because of injury due to accidents, reproductive failure. Udder disorders and disease conditions, i.e. was done involuntary. Traits studied were total milk yield (TMY), 305 days milk yield (305 DMY), lactation length (LL) and dry period (DP), considered as milk production traits. reproductive traits studied were calving interval (CI) (defined as the number of occurring between two successive parturitions), days open (DO) defined as the interval from calving to conception (i.e. the number of days between calving and the insemination that resulted in successful conception), and age at first calving, AFC (defined as number of months between date of birth and date of first parturition of a cow.

\section{Data statistical analysis.}

The General liner Model (GLM) was utilized for variance analysis of milk yield and reproductive traits. Duncan's multiple rang test (DMRT) was used for multiple comparisons of each trait. Data of milk production and reproductive traits of all available lactations were analyzed by a adopting the following mixed Model: $\mathrm{Y}_{\mathrm{ijklm}}=\mu+\mathrm{O}_{\mathrm{i}}+\mathrm{S}_{\mathrm{j}}+\mathrm{P}_{\mathrm{k}}+\mathrm{Y}_{1}+\mathrm{e}_{\mathrm{ijk} \mathrm{km}}$

Where: $\mathrm{Y}_{\mathrm{ijklm}}=$ on observation on DMY, 305-DMY, LL and DP., $\mu=$ general mean, common element to al observation., $\mathrm{O}_{\mathrm{i}}=$ fixed effect of the ith country of animal origin ( $\mathrm{i}=$ imported and local)., $\mathrm{S}_{\mathrm{j}}=$ fixed effect of the $j$ th season of calving $(\mathrm{j}=1,2,3$, and 4 , $1=$ winter, $2=$ summer $3=$ spring and $4=$ autumn)., $P_{k}$ 
$=$ fixed effect of the $k$ th parity $(\mathrm{k}=1-5)$., $\mathrm{Yl}=$ fixed effect of the lth year of calving $(1=1-9)$ and $e_{i j k l m}=$ random error particular to the ijklm observation a assumed to be independently randomly distributed with mean zero and variance $\delta^{2}$ e, i.e., NID $\left(0, \delta^{2} e\right)$. It includes all the other effects not specified in the model of the analysis.

\section{RESULTS}

1 - Milk Production traits:

\section{1 - a. Total milk yield and 305 day milk yield:}

The literature reviewed revealed that most important milk production traits (lactation milk yield, 305-day milk yield, length of lactation period, dry period) are influenced by many non-genetic effects, such as animal origin, calving season, parity and calving year. Least Squares Means \pm Standard errors of the effect of cows origin, calving season, parity and calving year on total milk yield, and 305-day milk are presented in Table 1.

Table 1: Least square means and standard errors (LSM \pm SE) of some factors affecting Lactation milk yield (LMY, kg) and 305-days milk yield (305-DMY, kg)

\begin{tabular}{|c|c|c|c|}
\hline \multirow{2}{*}{ Items } & \multirow{2}{*}{$\mathbf{N}$} & \multicolumn{2}{|c|}{$\mathrm{LSM} \pm \mathrm{SE}$} \\
\hline & & Total milk yield & 305 day milk yield \\
\hline Overall mean & 1974 & $2868.54 \pm 43.03$ & $2912.68 \pm 41.21$ \\
\hline Animal origin & & $* *$ & $* *$ \\
\hline Imported & 383 & $2978.33 \pm 56.81^{\mathrm{a}}$ & $2992.00 \pm 52.88^{\mathrm{a}}$ \\
\hline Local & 1591 & $2758.74 \pm 30.00^{\mathrm{b}}$ & $2833.35 \pm 27.92^{b}$ \\
\hline Calving season & & $\mathrm{NS}$ & $*$ \\
\hline Winter & 546 & $2825.67 \pm 39.48^{a}$ & $2930.91 \pm 36.74^{\mathrm{ab}}$ \\
\hline Spring & 311 & $2886.76 \pm 48.81^{\mathrm{a}}$ & $2822.68 \pm 45.43^{c}$ \\
\hline Summer & 469 & $2875.81 \pm 41.19^{\mathrm{a}}$ & $2925.56 \pm 38.34^{b}$ \\
\hline Autumn & 648 & $2885.90 \pm 38.17^{a}$ & $2971.56 \pm 35.52^{\mathrm{a}}$ \\
\hline Parity & & $* *$ & $* *$ \\
\hline $1^{\text {st }}$ & 428 & $2567.82 \pm 49.25^{\mathrm{d}}$ & $2503.48 \pm 45.84^{\mathrm{c}}$ \\
\hline $2^{\text {nd }}$ & 430 & $2936.72 \pm 45.72^{\mathrm{a}}$ & $2969.08 \pm 42.55^{\mathrm{a}}$ \\
\hline $3^{\text {rd }}$ & 427 & $2951.12 \pm 43.74^{\mathrm{ab}}$ & $3022.31 \pm 40.71^{\mathrm{ab}}$ \\
\hline $4^{\text {th }}$ & 372 & $2977.57 \pm 45.03^{b c}$ & $3053.72 \pm 41.91^{\mathrm{ab}}$ \\
\hline $5^{\text {th }}$ & 317 & $2909.44 \pm 47.84^{\mathrm{dc}}$ & $3014.79 \pm 44.52^{b}$ \\
\hline Year of calving & & $* *$ & $* *$ \\
\hline $1987-1988$ & 70 & $3275.10 \pm 107.8^{\mathrm{a}}$ & $3466.84 \pm 100.37^{\mathrm{a}}$ \\
\hline $1989-1990$ & 210 & $3189.16 \pm 61.23^{\mathrm{a}}$ & $3139.28 \pm 56.99^{a b}$ \\
\hline $1991-1992$ & 246 & $2909.37 \pm 50.15^{b}$ & $2990.63 \pm 46.68^{\mathrm{cb}}$ \\
\hline $1993-1994$ & 256 & $3005.12 \pm 55.40^{\mathrm{b}}$ & $2964.45 \pm 51.56^{c}$ \\
\hline $1995-1996$ & 334 & $3296.00 \pm 55.15^{\mathrm{a}}$ & $3319.12 \pm 51.32^{\mathrm{a}}$ \\
\hline $1997-1998$ & 356 & $2923.56 \pm 54.72^{\mathrm{b}}$ & $3020.36 \pm 50.92^{\mathrm{cb}}$ \\
\hline $1999-2000$ & 301 & $2819.31 \pm 59.84^{b}$ & $2855.52 \pm 55.69^{c}$ \\
\hline $2001-2002$ & 145 & $2255.64 \pm 76.95^{c}$ & $2255.98 \pm 71.62^{d}$ \\
\hline $2003-2004$ & 56 & $2143.55 \pm 112.8^{c}$ & $2201.88 \pm 104.9^{d}$ \\
\hline
\end{tabular}

$*=(\mathrm{P}<0.05),{ }^{*}=(\mathrm{P}<0.01), \mathrm{NS}=(\mathrm{P}>0.05)$. ${ }^{\mathrm{a}, \mathrm{b}}$ : Means within the same classification followed by different letters differ significantly $(\mathrm{P}<0.05)$

\section{1 - b. Lactation length (LL) and dry period (DP):}

Least squares means \pm SE of some factors affecting lactation length (LL) and dry period (DP) are presented in Table 2. The overall mean of LL and DP obtained in this study were $306.15 \pm 3.98$ and $95.05 \pm 4.45$ days, respectively. 
Table 2: Least square means and standard errors ( $\mathrm{LSM} \pm \mathrm{SE}$ ) of some factors affecting lactation Length (LL, days) and dry period (DP, days).

\begin{tabular}{|c|c|c|c|}
\hline \multirow[t]{2}{*}{ Items } & \multirow{2}{*}{$\mathbf{N}$} & \multicolumn{2}{|c|}{$\mathbf{L S M} \pm \mathbf{S E}$} \\
\hline & & Lactation length & Dry period \\
\hline Overall mean & 1974 & $306.15 \pm 3.98$ & $95.05 \pm 4.45$ \\
\hline Animal origin & & N S & N S \\
\hline Imported & 383 & $307.99 \pm 5.59^{\mathrm{a}}$ & $93.19 \pm 5.87^{\mathrm{a}}$ \\
\hline Local & 1591 & $304.27 \pm 2.95^{\mathrm{a}}$ & $96.88 \pm 3.47^{\mathrm{b}}$ \\
\hline Calving season & & $* *$ & $* *$ \\
\hline Winter & 546 & $301.73 \pm 3.92^{\mathrm{b}}$ & $95.18 \pm 4.11^{\mathrm{ab}}$ \\
\hline Spring & 311 & $320.02 \pm 4.86^{\mathrm{a}}$ & $98.92 \pm 5.00^{\mathrm{a}}$ \\
\hline Summer & 469 & $303.07 \pm 4.09^{\mathrm{b}}$ & $97.89 \pm 4.37^{\mathrm{ab}}$ \\
\hline Autumn & 648 & $303.61 \pm 3.76^{b}$ & $88.14 \pm 4.08^{\mathrm{b}}$ \\
\hline Parity & & $* *$ & N S \\
\hline $1^{\text {st }}$ & 428 & $320.78 \pm 4.85^{\mathrm{a}}$ & $93.33 \pm 4.62^{\mathrm{a}}$ \\
\hline $2^{\text {nd }}$ & 430 & $304.90 \pm 4.50^{\mathrm{b}}$ & $90.60 \pm 4.26^{\mathrm{a}}$ \\
\hline $3^{\text {rd }}$ & 427 & $302.57 \pm 4.30^{\mathrm{b}}$ & $92.65 \pm 4.10^{\mathrm{a}}$ \\
\hline $4^{\text {th }}$ & 372 & $303.40 \pm 4.43^{\mathrm{b}}$ & $91.41 \pm 4.28^{\mathrm{a}}$ \\
\hline $5^{\text {th }}$ & 317 & $299.01 \pm 4.71^{\mathrm{b}}$ & $107.1 \pm 9.72^{\mathrm{a}}$ \\
\hline Year of calving & & $*$ & $* *$ \\
\hline $1987-1988$ & 70 & $293.55 \pm 10.6^{\mathrm{abc}}$ & $95.32 \pm 9.98^{\mathrm{bc}}$ \\
\hline $1989-1990$ & 210 & $318.08 \pm 6.03^{\mathrm{a}}$ & $108.5 \pm 5.91^{\mathrm{ab}}$ \\
\hline $1991-1992$ & 246 & $308.07 \pm 4.94^{\mathrm{abc}}$ & $116.1 \pm 5.01^{\mathrm{a}}$ \\
\hline $1993-1994$ & 256 & $314.08 \pm 5.45^{\mathrm{ab}}$ & $93.18 \pm 5.81^{\mathrm{bc}}$ \\
\hline $1995-1996$ & 334 & $308.52 \pm 5.43^{\mathrm{abc}}$ & $92.93 \pm 5.46^{\mathrm{bc}}$ \\
\hline $1997-1998$ & 356 & $301.16 \pm 5.39^{\mathrm{bc}}$ & $92.49 \pm 5.54^{\mathrm{bc}}$ \\
\hline $1999-2000$ & 301 & $304.00 \pm 5.89^{\mathrm{bc}}$ & $83.25 \pm 6.23^{\mathrm{c}}$ \\
\hline $2001-2002$ & 145 & $309.62 \pm 7.58^{\mathrm{abc}}$ & $85.63 \pm 7.86^{\text {bc }}$ \\
\hline $2003-2004$ & 56 & $298.09 \pm 11.1^{\mathrm{c}}$ & $87.76 \pm 12.7^{\mathrm{bc}}$ \\
\hline
\end{tabular}

$*=(\mathrm{P}<0.05), * *=(\mathrm{P}<0.01) ., \mathrm{NS}=(\mathrm{P}>0.05)$. ${ }^{\mathrm{a}, \mathrm{b}}$ : Means within the same classification followed by different letters differ significantly $(\mathrm{P}<0.05)$.

\section{2 - Reproductive traits:}

\section{2. a. Days open (DO) and calving interval $(\mathrm{CI})$ :}

Least squire means and standard error for service period (days open) and calving interval as affected by different factors such as animal origin, calving season, parity and year of calving are presented in Table 3. 
Table 3: Least square means and standard errors (LSM \pm SE) of some factors affecting days open (DO, days) and calving interval (CI, days).

\begin{tabular}{|c|c|c|c|c|}
\hline \multirow[t]{2}{*}{ Items } & \multirow[t]{2}{*}{$\mathbf{N}$} & $\mathrm{LSM} \pm \mathrm{SE}$ & \multirow[t]{2}{*}{$\mathbf{N}$} & \multirow{2}{*}{$\begin{array}{l}\mathbf{L S M} \pm \mathbf{S E} \\
\text { Calving interval }\end{array}$} \\
\hline & & Days open & & \\
\hline Overall mean & 1470 & $115.11 \pm 5.74$ & 1649 & $396.93 \pm 5.77$ \\
\hline Animal origin & & $\mathrm{NS}$ & & $* *$ \\
\hline Imported & 307 & $117.90 \pm 7.65$ & 323 & $391.25 \pm 7.80^{b}$ \\
\hline Local & 1163 & $112.31 \pm 4.76$ & 1326 & $402.61 \pm 3.82^{\mathrm{a}}$ \\
\hline Calving season & & $* *$ & & $* *$ \\
\hline Winter & 422 & $105.57 \pm 5.50^{\mathrm{b}}$ & 470 & $387.87 \pm 5.37^{b}$ \\
\hline Spring & 243 & $133.54 \pm 6.67^{\mathrm{a}}$ & 274 & $416.09 \pm 6.55^{\mathrm{a}}$ \\
\hline Summer & 327 & $113.60 \pm 5.82^{b}$ & 378 & $397.32 \pm 5.72^{b}$ \\
\hline Autumn & 478 & $107.72 \pm 5.44^{\mathrm{b}}$ & 527 & $386.46 \pm 5.25^{b}$ \\
\hline Parity & & $\mathrm{NS}$ & ------ & ------------------ \\
\hline $1^{\text {st }}$ & 358 & $106.89 \pm 6.41^{\mathrm{a}}$ & ------ & ----------- \\
\hline $2^{\text {nd }}$ & 400 & $116.30 \pm 5.58^{\mathrm{a}}$ & ------ & ---------- \\
\hline $3^{\text {rd }}$ & 360 & $114.71 \pm 5.50^{\mathrm{a}}$ & ------ & ------ \\
\hline $4^{\text {th }}$ & 307 & $115.22 \pm 5.58^{\mathrm{a}}$ & ------ & ------- \\
\hline $5^{\text {th }}$ & 45 & $122.42 \pm 13.0^{\mathrm{a}}$ & ------ & --------- \\
\hline Year of calving & & $* *$ & & $* *$ \\
\hline $1987-1988$ & 68 & $116.13 \pm 12.6^{\mathrm{bc}}$ & 70 & $403.74 \pm 12.3^{\mathrm{b}}$ \\
\hline $1989-1990$ & 188 & $131.26 \pm 7.69^{\mathrm{a}}$ & 203 & $429.71 \pm 7.14^{\mathrm{a}}$ \\
\hline $1991-1992$ & 190 & $127.75 \pm 6.55^{\mathrm{ab}}$ & 214 & $427.48 \pm 6.59^{\mathrm{a}}$ \\
\hline $1993-1994$ & 184 & $122.48 \pm 7.75^{\mathrm{bc}}$ & 217 & $398.03 \pm 7.83^{\mathrm{ab}}$ \\
\hline $1995-1996$ & 265 & $121.39 \pm 7.06^{\mathrm{abc}}$ & 286 & $396.43 \pm 7.41^{\mathrm{ab}}$ \\
\hline $1997-1998$ & 285 & $112.91 \pm 7.17^{c}$ & 304 & $385.23 \pm 7.32^{b c}$ \\
\hline $1999-2000$ & 200 & $105.14 \pm 8.21^{\mathrm{c}}$ & 219 & $380.88 \pm 8.04^{\mathrm{bc}}$ \\
\hline $2001-2002$ & 64 & $109.18 \pm 11.9^{c}$ & 103 & $388.22 \pm 10.5^{b c}$ \\
\hline $2003-2004$ & 26 & $90.58 \pm 17.9^{\mathrm{d}}$ & 33 & $362.67 \pm 17.3^{c}$ \\
\hline
\end{tabular}

$*=(\mathrm{P}<0.05),{ }^{*}=(\mathrm{P}<0.01)$. $, \mathrm{NS}=(\mathrm{P}>0.05),{ }^{\mathrm{a}, \mathrm{b}}$ : Means within the same classification followed by different letters differ significantly $(\mathrm{P}<0.05)$.

\section{2.b. Age at first calving $(A F C)$ :}

Least square means and standard errors of some factors affecting age at first calving (AFC, days) are presented in Table 4.

Table 4: Least square means and standard errors (LSM \pm SE) of some factors affecting age at first calving (AFC, days)

\begin{tabular}{lcc}
\hline Items & $\mathbf{N}$ & LSM \pm SE \\
\cline { 2 - 3 } & 1965 & Age at first calving \\
\hline Overall mean & & $907.75 \pm 3.06$ \\
\hline Animal origin & 412 & $* *$ \\
Imported & 1553 & $844.36 \pm 7.64^{\mathrm{b}}$ \\
Local & & $971.14 \pm 4.05^{\mathrm{a}}$ \\
\hline Season & 457 & $*$ \\
Winter & 288 & $942.31 \pm 5.18^{\mathrm{b}}$ \\
Spring & 522 & $963.96 \pm 6.59^{\mathrm{a}}$ \\
Summer & 696 & $967.71 \pm 5.08^{\mathrm{a}}$ \\
Autumn & & $963.14 \pm 4.35^{\mathrm{a}}$ \\
\hline Calving year & 360 & $* *$ \\
$1987-1988$ & 334 & $843.55 \pm 5.99^{\mathrm{e}}$ \\
$1989-1990$ & 267 & $956.11 \pm 5.90^{\mathrm{c}}$ \\
$1991-1992$ & 277 & $1038.7 \pm 6.46^{\mathrm{b}}$ \\
$1993-1994$ & 320 & $1075.3 \pm 6.57^{\mathrm{a}}$ \\
$1995-1996$ & 337 & $936.41 \pm 6.02^{\mathrm{c}}$ \\
$1997-1998$ & 70 & $915.69 \pm 5.80^{\mathrm{d}}$ \\
$1999-2000$ & & $949.08 \pm 13.4^{\mathrm{c}}$ \\
\hline$*=(\mathrm{P}<0.05), * * *(\mathrm{P}<0.01)$. & ${ }^{\mathrm{a}, \mathrm{b}}:$ Means within the same classification followed by different letters differ significantly \\
$(\mathrm{P}<0.05)$. & & \\
& &
\end{tabular}




\section{DISCUSSION}

\section{1 - Milk production traits:}

\section{1.a. Total milk yield (TMY):}

The overall means of total milk yield and 305-DMY in this study averaged $2868.5 \mathrm{~kg}$ and $2912.7 \mathrm{~kg}$, respectively. These values were higher than those previously reported as 2730 and $2673 \mathrm{~kg}$ by Morsy et al., (1986) for TMY and 305-DMY, respectively. On the other hand, the values of TMY and 305DMY were lower than the values of $3698 \mathrm{~kg}$ TMY and $3211.5 \mathrm{~kg}$ 305-DMY reported by Marzouk (1998). Results in Table 1. Indicate that, milk production of the daughters of the imported cow's averaged $2758.7 \pm 27.14 \mathrm{~kg}$, being $7.4 \%$ lower than that of their mothers' $(2978.33 \pm 56.81)$ raised under the same environment. The relative low milk production of locally born cows was somewhat unexpected. Differences in milk production between cows born locally and those imported was significant $(\mathrm{P}<0.01)$. These results are consistent with Marzouk (1998). They reported that total milk yield of farm born Holstein Friesian and Jersey cows was significantly $(\mathrm{P}<0.05)$ lower than that of the imported Holstein Friesian and Jersey cows. All lactation of the imported cows and their progeny completed in Egypt were used to estimate the effects of season and parity. No significant effect was observed for season of calving on total milk yield. Average milk yield ranged from $2825.67 \mathrm{~kg}$ in winter to $2886.76 \mathrm{~kg}$ in spring (Table 1). The relatively higher milk yield of cows calving in spring could be attributed to temperature favorable for Friesian. Similar results were reported by Marzouk (1998) and Usman et al. (2012). However, M'hamdi et al.,(2012) did not agree with the findings of the present investigation. Least squares means \pm standard errors of total milk yield for the first lactation was $2567.82 \mathrm{~kg}$, being lower than means of the other parities and the differences between means were significant $(\mathrm{P}<0.01)$. The present results were in agreement with the findings of Usman et al., (2012) reported that total milk yield was significantly affected by lactation number. Analysis of variance indicated that the effect of year of on TMY and 305-DMY was significant $(\mathrm{P}<0.01)$ (Table 1). These findings are in agreement with those reported by M'hamdi et al., (2012) and Rehman et al., (2014). The results did not show a certain trend. LSMs oscillates across the studied years, the highest mean was in 1995/1996 (3296 kg) and the lowest in 2003/2004 (2143.5 kg). Differences among LSMs were significant $(\mathrm{P}<0.05)$, the decline in milk production in the last years of the study may be due to the accumulation of undesirable genetic factors due to the inbreeding of the herd, where the herd was later disposed of for poor production.

\section{1.b. 305 day milk yield (305-DMY):}

Least squares means and their standard error of effect of animals origin on 305-DMY are presented in Table 1. Origin of animals had significant $(\mathrm{P}<0.01)$ effect on 305-DMY. Average of 305-DMY was higher in imported cows compared to that the locally-born ones. The findings of present study are in accordance with the findings of Marzouk (1998) and Ali et al., (1999a), who reported that the effect of origin of animals on 305-DMY was significant. The differences in milk production may be due to a change in environmental conditions, management practices and nutrition, as well as the difference in genotypes between two groups of animals.

The least squares analysis revealed that 305 days milk yield was significantly $(\mathrm{P}<0.05)$ affected by season of calving (Table 1). The present results suggested that milk yield was sensitive to seasonal variation. The effect of calving season on 305-DMY was significant and 305-DMY was higher (2971.56 \pm 35.52 ) in cows calving in autumn compared to spring seasons. Cows calving in autumn have high 305-DMY due probably to good feeding levels in the first 3 or 4 months of lactation. On the contrary, Bilal et al. (2014) observed that the season of calving had a non-significant effect on lactation milk yield in Holstein Friesian cows. 305-days milk yield differed significantly $(\mathrm{P}<0.01)$ with lactation order (Table1). The 305-days milk yield in second lactation was significantly higher than in first lactation. This result is consistent with Munim et al. (2006) who found significant $(\mathrm{P}<0.05)$ effect of parity on milk yield. The significant effect of parity on productive performance may be due to the increase in production is caused by maturation and increase in body weight and mammary gland. Mammary gland grows and develops parallel to growing, maturation and recurring pregnancies and lactations (Anderson, 1985).

Results of analyzing the data of milk production traits by using the least-squares means \pm SE gave evidence that year of calving was found to have significant $(\mathrm{P}<0.01)$ effect on 305 -day milk yield (Table 1). This significant effect obtained here in was confirmed by findings on 305-day milk yield by Nadia Fahim, (2004). Effect of calving year on all milk yield traits was significant. Differences among years may be related to management. It can be said that differences of management among years was the most important factor affecting milk yield traits. Lower productivity of Friesian cows in 2004 than the cows in 1987 may be attributed to no genetic improvement in herd breeding or the cumulative effect of environmental conditions on the offspring. 


\section{1.c. Lactation length (LL):}

Lactation length is an important production trait as it influences the total milk yield. In most modern dairy farms, a lactation length of 305 days commonly accepted as a standard. This standard allows for calving every 12 months with a 60-day dry period (Wondifraw et al., 2013). The 12-month interval has considered "Ideal" for many years. If a cow milked longer than 305 days, her yield for the first 305 days taken as the lactation yield. Some cows are not milked for a full 305 days because they go dry or the lactation terminated for any of several reasons. These short records projected to a 305 days equivalent (Wondifraw et al., 2013). The average lactation length for records was $306.15+3.98$ days, lactation length in the imported Friesian cows averaged $307.99 \pm 5.59$ days while in the local-born Friesian it was $304.27 \pm 2.95$ days. The imported group of Friesian cattle showed no statistical differences from locally born cattle in terms of lactation length. Afridi, (1999) reported almost similar findings $(315.09 \pm 17.75$ days) in Friesian cows in Pakistan. But Juneja et al. (1991) recorded longer (344 days) lactation length in Friesian cows in India.

Least-squares analyses of variance presented in Table (2) evidenced significant $(\mathrm{P}<0.01)$ effect was observed for calving season on lactation period of the current study. In agreement with these results, significant season of calving effect was reported on length of lactation period (Afridi, 1999; Rehman et al., 2014; Usman et al., 2012 and M'hamdi et al., 2012). Cows calving in winter had the shortest (300.31 \pm 3.88 days) lactation period whereas those calving in spring had the longest $(319.02 \pm 4.80$ days) lactation length. The lactation period as well as the total milk yield were significantly $(\mathrm{P}<0.01)$ affected by parity order (Table 2 ). The first lactation period was the longest $(320.78 \pm 4.85$ days $)$ and the shortest lactation period $(299.01 \pm 4.71$ days $)$ was found in cows which calved for fifth time. However, the lactation period was not different from that of $2^{\text {nd }}, 3^{\text {rd }}$ and $4^{\text {th }}$ lactation. The present finding was in agreement with reports of M'hamdi et al. (2012). The year of calving had a significant effect $(\mathrm{P}<0.05)$ on lactation length of cows (Table 2). Lactation duration was shortest in 1989-1990 at 293.55 days and longest in 1991-1992 at 318.08 \pm 6.03 days. This result is in close agreement with reports of Wondifraw et al. (2013) found that there were significant differences in lactation length due to the effect of the calving year.

\section{1.d. Dry period (DP):}

Dry period is important for replacing senescent mammary epithelial cells and increasing the epithelial component of the gland prior to the next lactation (Sawa et al., 2012). The overall mean of
DP obtained in this study $(95.05 \pm 4.45$ days $)$, was higher than corresponding values obtained in Egypt, which ranged between 52 days (Afifi et al., 1999) and 125 days as reported by (Salem and AbdelRaouf, 1999). The present overall mean of DP on Friesian cattle in Egypt was longer than that reported by Oudah et al. (2001) (79.3 days); Salem et al., (2006) (64 days) and Shitta et al. (2002) (86 days), but it was shorter than reported by Marzouk (1998) (93.98 days); El-Arian et al. (2003) (108 days) and Salem and Abdel-Raouf (1999) (125 days). With regard to the effect of animal origin on DP, Table 2 indicates that animal origin had no significant effect on DP. Dry period were slightly lower $(96.88 \pm 3.47$ days) in the cows imported than locally-born daughters. The results of the present study considering all lactations were in line with the findings of other workers who reported that animal origin had no effect dry periods (Marzouk, 1998; Kaya et al., 2003 and Ali et al., 1999a). Animals calving in autumn season had shorter dry period (88.14 days) than those calving during winter (95.18 days), spring (98.92 days) and summer (97.89 days) seasons. Dry period was affected significantly $(\mathrm{P}<0.01)$ by calving season. The results are in conformity with those of Zewdu et al. (2015) and Abou-Bakr et al. (2006) they reported that season of calving had a significant effect on dry period.

The LSM for dry period in Friesian cows for $1^{\text {st }}, 2^{\text {nd, }}$ $3^{\text {rd }}, 4$ th and $5^{\text {th }}$ parity were $93.33 \pm 4.62,90.60 \pm 4.26$, $92.65 \pm 4.10,91.41 \pm 4.28$ and $107.1 \pm 9.72$ days, respectively (Table 2). The differences among LSM due to parity effect were no significant. The LSM for dry period recorded in $5^{\text {th }}$ parity is highest and lowest in $4^{\text {th }}$ parity. Similar non-significant effects were also shown by Gatchearle et al. (2010). Effects calving year on dry period were statistically significant $(\mathrm{P}<0.01)$. The dry period was lowest (83.25 \pm 6.23 days) in $1999 / 2000$ and highest $(116.1 \pm 5.01$ days) in $1991 / 1992$. Year wise means indicated that there was an increasing trend in lactation length from 1991/1992 to 2003/2004 (Table 2). Effect of calving year on all milk yield traits was significant. It can be said that differences of management among years was the most important factor affecting milk yield traits. Similar findings were reported by Rehman et al. (2014) and AbouBakr et al. (2006).

\section{2 - Reproductive traits:}

In seasonal and non-seasonal dairy production systems the predictable production of milk and young stock is dependent on calving pattern and for this reason; reproductive performance is a key determinant of profitability (Farin et al., 1994). 


\section{2.a. Days open (DO):}

Least squire means \pm SE of service period for imported and local porn Friesian cows was $117.90 \pm$ 7.65 and $112.31 \pm 4.76$ days, respectively (Table 3 ). Effect of origin of animals was not significant on days open. This result is consistent with Nazem et al. (2001), he found that effect of origin of the heifer (imported or locally born) was not significant on days open.

The least squire mean \pm SE of days open as affected by season are presented in Table 3. Season of calving had $(\mathrm{P}<0.01)$ highly significant effect on days open. Cows that calved in spring a greater number of days open (133.54 days), followed by cows calved in summer (113.6 days) then calved in autumn (107.72 days) and winter (105.57 days). Significant effect might be due to variations in atmosphere and feedstuffs available at different seasons of the year. The significant effect of calving season on days open was observed also by (Salem and Abdel-Raouf, 1999). Parity had no significant effect on DO. The fifth parity showed the longest DO $(122.42 \pm 13.0$ days $)$ while the $1^{\text {st }}$ parity calvers showed the lowest one $(106.89 \pm 6.41$ days $)$. This result is entirely consistent with the result obtained by Sadek et al. (2014), but does not agree with the results of Kaya et al. (2003) and Abou-Bakr et al. (2006). Year of calving was highly significant effect $(\mathrm{P}<0.01)$ on days open. Maximum values of DO were $131.26 \pm 7.69$ days for the year 1989/1990, while the lowest value were $90.58 \pm 17.9$ days for the year 2003/2004, respectively. As it is well known reproductive traits slightly affected by heredity, and is the biggest factor affecting the environmental conditions so we can return the effect of calving year on the open days to the change in climate, management and feeding from year to year. The significant influences of the year on days open were observed in many studies, such as (Oudah et al., 2001; Kaya et al., 2003 and Sadek et al., 2014).

\section{2.b. Calving interval (CI):}

Results listed in Table 3. Show that the actual overall mean of calving interval estimated by using records of all available lactations was $396.93 \pm 5.77$ days. This mean is lower than most of the reviewed means of the Egyptian studies Salem et al. (2006, 420 days) and higher than 372 days obtained by (Ahmed et al., 2002). Which results in Table 3 shows that there is a highly significant effect $(\mathrm{P}<0.01)$ of animal origin on calving interval. The mean calving interval in the imported and the local Friesian cows was 391.25 and 402.61 days respectively, and it was significantly $(\mathrm{P}<0.01)$ longer in the local born. These results are entirely consistent with the results obtained by Oudah et al.
(2001) showed that there were significant $(\mathrm{P}<0.05)$ differences in calving interval between imported and locally born heifers which it was longer in the local born. Similar results are also obtained by Nawaz et al. (1993) on Jersey cows. But, it was not agree with the results of Eid et al. (2012). They observed that the average calving interval was $468.9 \pm 116.3$ and $445.4 \pm 92.8$ days for imported and local bred Friesian cattle, respectively.

Calving interval was found to be significantly affected by season of calving (Table 3 ). The calving interval of the cows previously calved during spring season (416.09 days) was significantly $(\mathrm{P}<0.05)$ longer than those calved in all other season, while the difference among other season (winter, summer, and autumn season) were non-significant. In agreement with this finding, Tawfik et al. (2000) revealed that season of calving contributed significantly to the variance of calving interval. Results in (Table 3) revealed that year of calving was found to have significant effect on calving interval. This agrees well with findings of Eid et al. (2012) and Abou-Bakr et al. (2006) who evidenced that year of calving effect on calving interval was significant.

\section{2.c. Age at first calving (AFC):}

As shown in Table 4. The age at first calving in the local born Friesian was significantly higher $(\mathrm{P}<0.01)$ than the imported Friesian cows (971.14 vs. 844.36 days). The present results were in conformity with the finding of the following workers, who reported that age at first calving differed significantly at different locations for imported and local born cows (Ali et al., 1999b and Kaya et al., 2003). The age at first calving in the imported Holstein Friesian was significantly higher $(\mathrm{P}<0.01)$ than the locally born (Ali et al., 1999b). Friesian cows born in winter season were significantly early than those born in all other season and the difference among those other seasons was insignificant (Table 4). Season of birth effect was found to contribute significantly $(\mathrm{P}<0.05)$ to the variance in age at first calving by different investigators (Rehman et al., 2014; Kaya et al., 2003; Oudah et al., 2001; Usman et al., 2012). Year of birth had a highly significant on age at first calving. The values of age at first calving were ranged from $843.55 \pm 5.99 \& 1075.30$ days for 1987 1988 and 1993-1994 respectively (Table 4). Year of birth effect constituted an important source of variation in age at first calving of the dairy cow by many investigators, i.e. year of birth was found to have significant effect $(\mathrm{P}<0.01)$ on age at first calving (Rehman et al., 2014 and Sadek et al., 2014). All these findings might indicate the importance of year of birth as a factor influencing age at first calving. 


\section{IN CONCLUSION}

It could be stated that Friesian cows born and raised in Egypt were better in some reproductive traits, while imported cows tended to have more total milk yield. Parities and year of calving from environmental factors had significant effects on milk and reproductive traits. Thus, improvement of environmental conditions may a sound impact on improving reproductive traits.

\section{REFERENCES}

Abou-Bakr, S.; Alhammad, H.O.A.; Sadek, R. and Nigm, A.A. (2006): Productive and reproductive characteristics of Holstein cowsrasied under intensive farming system in Egypt. Egyptian J. Anim. Prod., 43(2): 91-98.

Afifi, E.A.; Hamdia H. Khalil; Zahed, S.M. and Gad, M.E. (1999): Performance of Friesian, Holstein Friesian and Brown Swiss cattle in the first lactation under the Egyptian conditions. Annals of Agric. Sci., Moshtohor, 37 (4): 2275-2290.

Afridi, R.J. (1999): Productive performance of Holstein-Friesian cattle in North West Frontier Province (NWFP) of Pakistan. Pakistan Veterinary Journal, 19(4), 192-196.

Ahmed, A.M.; El-Asheeri, A.K.; Ibrahim, M.A.M. and Barkawi. (2002): Impact of milk yield on economics of Holstein herds under Egyptian conditions. Egypt. J. Anim. Prod. 39:1.

Ali, I.; Miza, R.H. and Nasir, A.A. (1999a): Productive and reproductive efficiency of imported and local born Jersey breed of cattle in the subtropical environmental of Pakistan. Pak. J. Biol. Sci., 2:220.

Ali, I.; Nasir, A.A. and Miza, R.H. (1999b): Comparative performance between imported and local born Holstein Friesian cows maintained at LES B hunikey. Pak. J. Biol. Sci., 2:207.

Anderson, R.R. (1985): Mammary gland. In: Lactation (Ed.: Larson, B.L.). Ames, The Iowa State University Press 1985; p. 276.

Bilal, M.; Lodhi, M.Y.; Chawanakul, S. and Kakar, M.A. (2014): Productive and reproductive profile of Holsteins kept in Balochistan Province, Pakistan. Reproduction Fertility and Development 17(2):245-245.

Duncan, D.B. (1955): Multiple range and multiple F test Biomerics, 11:1- 42

Eid, I.I.; Elsheikh, M.O. and Yousif, I.A.S. (2012): Estimation of genetic and non-genetic parameters of Friesian cattle under hot climate. J. Agri. Sci., Vol. 4, No. 4.

El-Arian, M.N.; El-Awady, H.G. and Khattab, A.S. (2003): Genetic analysis for some productive traits of Holstein Friesian cows in Egypt through MTDFREML program Egypt J. Anim. Prod, 40: 99.

FAO (2010): FAOSTAT Database Results, http: // www.fao.org.

Farin, P.; Slenninq, B.; Correa, M. and Britt, J. (1994): Effects of calving season and milk yield on pregnancy risk and income in North Carolina Holstein cows. J. Dairy Sci., 77: 1848-1855.

Gatchearle, P.L.; Mitkari, K.R.; Mule, R.S.; Baswade, S.V. and Bhadekar, S.V. (2010): Effect of season of calving and parity on dry period and intercalving period in interse progeny of HF X Deoni. Veterinary World, Vol.3 (2): 85-87.

Juneja, I.J.; Sastry, N.S.R. and Yadav, B.L. (1991): Performance of purebred herd of Jersey and Holstein-Friesian cows in the semi-arid region. Indian J. Anim. Prod. Management, 7: 240-241.

Kaya, I.; Uzmay, C.; Kaya, A. and Akbas, Y. (2003): Comparative analysis of milk yield and reproductive traits of Holstein-Friesian cows born in Turkey or imported from Italy and kept on farms under the Turkish-ANAFI project. Ital. J. Anim. Sci. (2): 141-150.

M'hamdi, N.; Bouallegue, M.; Frouja, S.; Ressaissi, $Y$.; Kaur Brar, S. and Ben Hamouda, M. (2012): Effects of environmental factors on milk yield, lactation length and dry period in Tunisian Holstein cows. Milk production An Up-to-Date Overview of Animal Nutrition, Management and Health.

Marzouk, K.M. (1998): A comparison between imported and locally born Friesiancows in Egypt. J. Agric. Sci. Mansoura Univ., 23(12): 5853-5861.

Morsy, M.A.; Nigm, A.A.; Sadek, R.R. and El-Rawy, A. (1986): Some production characteristics of Friesoian and Jersey cattle in Lybia. Egyptian J. Anim. Prod, 26 (1): 15-35.

Munim, T.; Hussein, S.; Hoque, M. and Khandoker, M. (2006): Genetic and non-genetic effects on productive and reproductive traits of different genetic groups of cows, Bangladeshi Journal of Animal Science, 35(1\&2): 1-12.

Nadia Fahim, N.H. (2004): A study on milk yield and persistency of a Holstein herd in Egypt M.Sc. Thesis Fac. Agric, Cairo Univ. Cairo; Egypt.

Nawaz, M.; Anwar, M.; Mirza, M.A. and Nawaz, R. (1993): Study of comparative milk production and reproduction of Jersey cattle under USA and Pakistan conditions. AJAS vol. 6 (No. 4) 549-553.

Nazem, A.; Shalaby, El-Said Z.M. Oudah and Mahmoud Abdel-Momin. (2001): Genetic Analysis of Some Productive and Reproductive Traits and Sire Evaluation in Imported and Locally Born Friesian Cattle 
Raised in Egypt. Pakistan Journal of Biological Sciences, 4: 893-901.

NRC (National Research Council) (1975): "Nutrient Requirements of dairy cattle $6^{\text {th }}$ the revised. Ed. National Academy Press, Washington Dc, USA.

Oudah, E.Z.M.; Shalaby, N.A and Mustafa, M.A. (2001): Genetic and nongenetic factors affecting days open, number of service per conception and age at first calving in a herd of Holstein-Friesian cattle. Pakistan Journal Biological Sciences, 4(6): 740-744.

Rehman, Z.; Khan, M.S. and Mirza, M.A. (2014): Factors affecting performance of Sahiwal cattle - a review. J. Anim. Plant Sci. 24(1).

S.A.S. (1996): Statistical analysis system. SAS USER'S Guide: Statistics. SAS Institute Ine. Editors, Cary, NC.

Sadek, R.R.; Ashour, G.; Ibrahim, M.A.M. and Samoul, A.M. (2014): Effect of daily weight gain on age at first calving and subsequent milk yield of Holstein heifers in Egypt. Egyptian J. Anim. Prod, 51(3):164-171.

Salem, M.A.; Esmoil, H.M.; Sadek, R.R. and Nigm, A.A. (2006): Phenotypic and genetic parameters of milk production and reproductive performance of Holstein cattle under the intensive production system in Egypt. Egyptian J. Anim. Prod., 43 (1): 1-10.

Salem, A.Y. and Abdel-Raouf, E.M. (1999): Genetic study of fertility and productive traits in a commercial herd of Holstein-Friesian cattle in Egypt. J. Agric. Res. Tanta Univ., 25: 191203.

S.A.S. (1996): Statistical analysis system. SAS USER'S Guide: Statistics. SAS Institute Ine. Editors, Cary, NC.
Sawa, A.; Mariusz Bogucki and Wojciech, N.E.J.A. (2012): Dry period length and performance of cows in the subsequent production cycle. Archiv Tierzucht 55 (2): 140-147.

Shalaby, N.A.; Oudah, E.Z.M. and Abdel-Momin, M. (2001): Genetic analysis of some productive and reproductive traits and sire evaluation in im[ported and locally born Friesian cattle raised in Egypt. Pakistan Journal Biological Sciences, 4(7): 893-901.

Shitta, A.A.; Tag El-Dein, M.A. and Eet El-Habaeib, S. Awad. (2002): A study on productive and reproductive traits of Friesian cattle in Egypt J. Agric. Sci. Mansoura Univ., (27): 7281.

Tawfik, E.S.; Mohsen, M.K.; Salem, A.Y. and ElAwady, H.G. (2000): Study onFriesian herds raised in Egypt and Germany i. Estimate of non-genetic effects and genetic parameters. Arch. Tierz., Dummerstorf, 43(2): 101-114.

Usman, T.G.; Guo, S.M.; Suhail, S.; Ahmed, L.; Qiaoxiang, M.S.; Qureshi and Wang, Y. (2012): Performance traits study of Holstein Friesian cattle under subtropical conditions. The Journal of Animal and Plant Sciences, 22(2): 92-95.

Wondifraw, Z.; Thombre, B.M. and Bainwad, D.V. (2013): Effect of non-genetic factors on milk production of Holstein Friesian $\times$ Deoni crossbred cows. Afr. J. Dairy Farming Milk Prod, 1(4): 079-084.

Zewdu, W.; Thombre, B.M. and Bainwad, D.V. (2015): Studies on some non-genetic factors affecting reproductive performance of Holstein Friesian x Deoni crossbred cows Afr. J. Agric. Res. Vol. 10(12), pp. 15081516.

\title{
الأداء الإنتاجى والتناسلى لأبقار الفريزيان تحت الظروف البيئية بأسيوط \\ حسن عبل الله حسن ، محترم عبل الله محد إبراهيم ، عبل الرحمن إبر/هيمزنونحى ، أحد عنتر عياد
}

Email: mohtaram_a_m_e@yahoo.com Assiut University web-site: www.aun.edu.eg

\begin{abstract}
تم جمع البيانات المستخدمة في هذه الدر اسة من هو9 ا سجل لابقار الفريزيان النقية في محطة أبنوب الحمام • ب كم شمال شرق مدينة

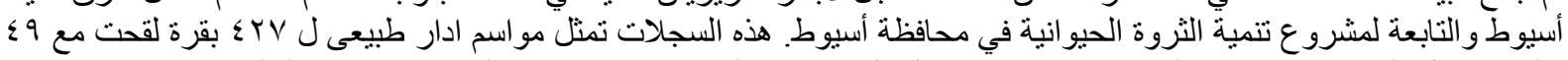

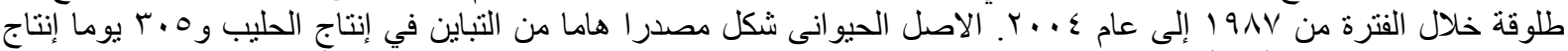

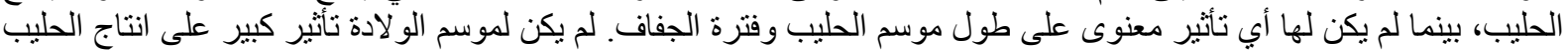

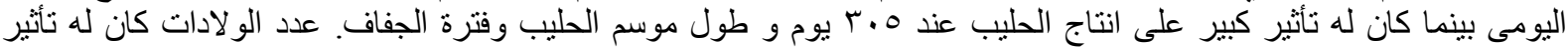

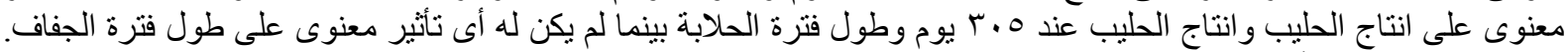

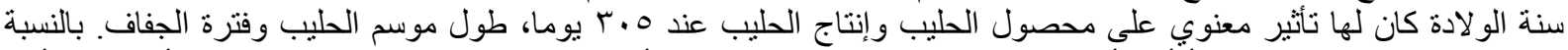

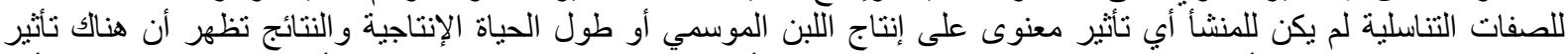

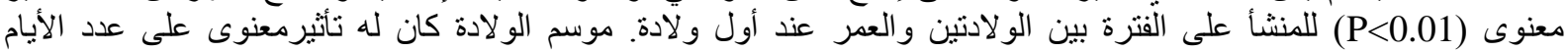

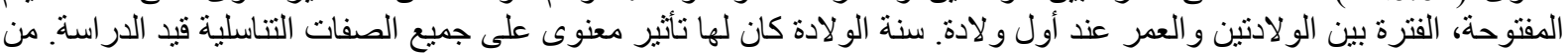

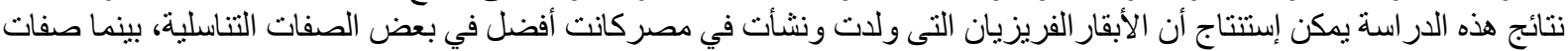

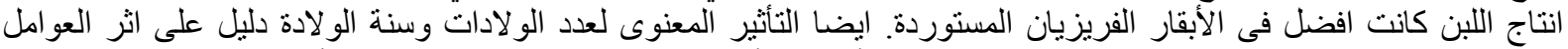

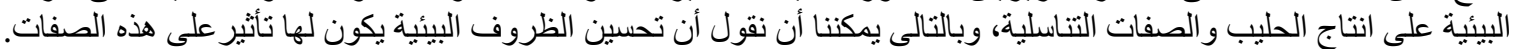

